\title{
Tribology and Dentistry: A Commentary
}

\author{
Antonio Lanza ${ }^{1, *}$, Alessandro Ruggiero ${ }^{2}\left(\mathbb{D}\right.$ and Ludovico Sbordone ${ }^{1}$ \\ 1 Department of Medicine, Surgery and Dentistry "Schola Medica Salernitana", School of Dentistry, \\ University of Salerno Via S. Allende, 84081 Baronissi, Italy; lsbordone@unisa.it \\ 2 Department of Industrial Engineering, University of Salerno, 84084 Fisciano, Italy; ruggiero@unisa.it \\ * Correspondence: alanza@unisa.it
}

Received: 14 May 2019; Accepted: 14 June 2019; Published: 20 June 2019

\begin{abstract}
Since 1966 the term "tribology" has integrated different topics like friction, lubrication and wear. After a few years, interest in this type of phenomena rapidly spread out around the world of biology and medicine, determining a new research area defined as biotribology. This commentary is conceived within this framework with the aim of underlining the close link between tribology and dentistry regarding both physiological and restorative issues. The contact between teeth requires investigation into their tribological behavior focusing on the enamel wear process against natural teeth and/or artificial teeth, allowing us to obtain useful information on the tribological behavior of restorative materials. Thus, tested materials may be natural teeth, restorative materials (metal alloys, ceramics, composites) or both. This work aims to make a contribution to underlining the need for greater standardization of tribological experimental procedures as well as to obtaining more homogeneous and indicative results on the tested tribo systems.
\end{abstract}

Keywords: biotribology; dentistry; wear; lubrication; enamel

\section{Introduction}

It is well known that although ancient Egyptian man dealt with problems relating to friction, wear and lubrication, tribology was officially born in the 1960s as described for the first time by Sir H. Peter Jost's group in the report presented to the UK Ministry of Education and Science [1].

In recent decades one of the fields of application, that has developed considerably, is biotribology which studies the relationships between tribology and biology considering also biomaterials and their use in the medical field [2]. In particular, in recent decades, with the introduction of numerous new materials: metallics, ceramics, polymerics, a remarkable interest developed in tribological research in dentistry.

In the masticatory organ it is possible to identify different structures. The teeth are surely the most important parts related to biotribology and play a fundamental role in our life, connected to functions like pronunciation, facial aesthetics and social relationships. All of these parts are under neuromuscular control [3].

Wear upon teeth, natural or artificial, is inevitable because they are continuously subjected to mechanical stress and chemical modifications. However, excessive wear can lead to a lack of ideal contact between opposite teeth, a disturbance in the efficiency of the masticatory system, and removal of the masticatory surfaces [4].

Dental wear is a physiological process in the life of the teeth [5]. Sometimes it can become excessive with loss of the occlusal surface, for instance in the case of overbite, bruxism and the lack of a tooth. This process of wearing of the dental cusps causes an increase in the contact area and, sometimes, an increase in wear.

To analyze the different types of wear between teeth and restorative materials properly, the oral cavity is usually compared to a tribological system. Basically the system is structured by four elements: 
- $\quad$ the first is a solid body which represents a tooth;

- the second is the counter-body, usually a solid (for example an object or an opposite tooth), a liquid, a gas or a combination of these elements;

- the third is the part between the first and the second described as the interfacial element, usually a solid (food bolus particles, etc.), a liquid which acts as a lubricant (saliva), less frequently a gas or a combination of these different elements;

- $\quad$ the fourth is the air, the environment where the wear activity usually happens.

\section{Teeth}

Teeth are very hard organs located inside the oral cavity. Their main function is to grab food and then to mechanically break down items of food by cutting and crushing them. A tooth is composed essentially of two parts: the dental crown, that is the part seen in the mouth, and the root, inserted into the bone. These two parts are connected by a transition zone, called the neck, where enamel is substituted by cementum.

Furthermore, the tooth is made up of a series of tissues [6]:

- dentin: is a hydrated biological composite, made of $70 \%$ inorganic material, $18 \%$ organic matrix, and $12 \%$ in weight by water. It is elastic and soft, it constitutes the skeleton of the tooth and has a yellow-orange color. Its structure includes oriented tubules surrounded by a highly mineralized cuff of peritubular dentin and an intertubular matrix. However, its properties and structural compositions are not the same in the external zone (near the enamel) and the internal one. Between enamel and dentin there is the enamel-dentin junction, a biological interface that can dissipate stresses, inhibiting a further propagation of cracks. Moreover, its importance is related to its ability to resist the impact forces that occur when the tooth is working;

- enamel: covers the dentin; it is very hard and resistant and is suitable for supporting the chewing. It has a thickness of $2-3 \mathrm{~mm}$, and is exposed to the occlusal surface and to the chemical environment inside the mouth. The high hardness of the enamel is attributed to the high mineral content, while its fragility is due to its high modulus of elasticity and low tensile strength;

- cement: is a very thin layer which covers the dentin on the whole surface of the root;

- pulp: provides sensitivity to the tooth and maintains the elasticity of the dentin.

From a tribo-mechanical point of view, enamel is one of the hardest tissues in the human body. It is made up of a structure formed by aligned prisms showing high resistance to wear. They are arranged perpendicularly to the dentin forming a protective layer which, in the occlusal part, reaches even $2 \mathrm{~mm}$ of thickness [7].

The enamel of human teeth is composed of $92-96 \%$ inorganic substances (crystallized in hydroxyapatite: $\left.\mathrm{Ca}_{5} \mathrm{PO}_{4} \cdot 3 \mathrm{OH}\right), 1-2 \%$ organic materials, and $3-4 \%$ water.

Between one prism and the other, the small organic enamel matrix is interposed, composed of two classes of proteins: the enameline and the amelogenins [8,9].

In the oral cavity, the presence of saliva is essential. Its functions is varied but, certainly, the most important is to make the contacts between the different structures of the mouth lubricated. In particular it:

- reduces friction between hard and soft tissues;

- reduces tooth wear;

- reduces friction between the mucous membranes

- lubricates the surfaces of the tongue optimizing the perception of taste;

- promotes wound healing.

Saliva is indispensable in the shredding of food, in the preparation of the food bolus, and in its swallowing. It has a role in the protection of dental enamel by promoting enamel remineralization mechanisms due to its buffering capacity and the content of fluorine and calcium ions [10]. 
Inside the oral cavity the organic acids-returning from the stomach to the mouth (intrinsic factors) or acids present in the diet (extrinsic factors) - spread first on the enamel surface, then penetrate the interplasmic spaces and dissolve the prismatic structures, freeing calcium phosphate. This process is called demineralization [11,12].

However, this is a reversible process since, in normal conditions, the ions deriving from calcium phosphates, naturally present in the saliva, contribute in the enamel remineralization, maintaining a stable equilibrium between the two processes (buffering capacity) [13].

Fluorine promotes the remineralization process: it binds to hydroxyapatite and transforms it into fluorapatite, a chemical element characterized by a molecular structure which makes it more resistant to acid attack. However, if acid attacks are frequent and prolonged, the effects of demineralization prevail compromising, among other things, the wear resistance of the teeth [14].

\subsection{Wear Types}

There are different causes determining the enamel consumption [15] and they are generally addressed as wear phenomena.

A comprehensive description of the current terminology in dentistry is reported by Mair L.H. [5].

Abrasive wear is the most common wear mechanism. On a microscopic scale no surface is entirely smooth and when there is contact between different bodies this happens through the contact of the asperities which act as abrasive particles against the other body.

In dentistry it is important to recognize that most of the wear due to surface-to-surface contact is not related only to the chewing process, but also to the patients involuntarily tightening or grinding teeth $[16,17]$. This type of wear is closely linked to the intensity of the forces applied to the teeth, to the number of contact teeth in the oral cavity, and to the bone supporting the teeth.

Regarding the assessment of the teeth dynamic loading, it is important to know that the masticatory system is a rather complex structure. There are numerous muscles different in shape and size with complex relationships [3] which do not allow an accurate univoce movement definition [18,19]. The masticatory movement takes place through the temporo-mandibular joints, characterized by two contact surfaces separated by a cartilaginous disc and wrapped by a network of ligaments which allows the jaw to move more, or less freely [20,21].

The complexity and the variability of the joint movements does not allow to reproduce them experimentally in a simple way [22].

It is possible to identify two different types of abrasive wear in relation to the contact materials: abrasive wear with two or three bodies.

\subsubsection{Two-Body Abrasion}

The two-body abrasion is generated through the friction between two moving solids in which the surfaces are in direct contact [23]. It is also possible to distinguish different two-body abrasion models, depending on the contact angle, surface topographies, the friction coefficient, the relative speed, contact pressure, the sliding distance, and the different hardness between the two contact surfaces [24]. In the case the two contact bodies have surfaces with a very significant differences in hardness, the micro-asperities on the harder surface generate grooves on the weaker one through a cutting mechanism. At the microscopic level, the abrasive "micro-tools" generate an effect similar to a plow, in which the material is continuously removed laterally, forming ridges near the generated grooves. In cyclical conditions, many grooves became parallel to the wear debris motion direction. When the closeness of the grooves increases, the result is a weaker structure with local deformations. Furthermore parts of material are removed by a fatigue wear mechanism.

In the case of different materials, fragile but with high hardness, as in the case of dental ceramics, micro-asperities on the hardest surface cut the most ductile surface of course, without plastic deformation, through a cutting mechanism. The shape and the volume of the grooves is exactly, in volume, equal to the the removed material. If in addition these two surfaces are also subjected to high 
contact pressures, some surface asperities are removed by a process of formation of micro-fractures. Small cracks, in fact, take place along the furrow and propagate up to remove a piece of surface material. Repeating these cycles, all surface asperities are subject to one or more of these models and then suffer a cumulative wear effect.

This type of wear mechanism is a gradual phenomenon which is mainly identified as a result of psychological and pathological friction between the proximal and occlusal surface of the teeth. As for the proximal surface, this type of wear is closely related to the forces being exerted in the chewing process and to their cumulative effects. Two factors are mainly responsible of this, the first is the relative lateral motion which induces friction between adjacent teeth and occurs along a perpendicular plane to the line identified by the contact points and is due to the visco-elasticity of the periodontal ligaments; the second factor is due to the closing movement occurring during the chewing phase, in which the teeth contract the alimentary bolus until the jaw begins to open. In this phase there are occlusal loads. They are distributed on the food bolus so as to trap food between the opposite surfaces of the teeth (especially the upper and lower molars) and allow them to be dragged. Therefore, the alimentary bolus is compressed and crushed, and the grinding occurs both through tooth-food-tooth contact (or also indirectly) and tooth-tooth (complete penetration of the food bolus). The occlusal forces are distributed over the entire dental arch [25], in this way the distal tooth is pushed onto the mesial which then come into contact.

In the dental arch, when the surfaces do not correspond exactly with each other, or if there is a difference in the degree of wear, one or more wear mechanisms can prevail or coexist and, therefore, it is not easy to carry out an accurate diagnosis and predict the main wear mechanism.

\subsubsection{Three-Body Abrasion}

The three-body abrasion occurs when there are two bodies in mutual motion, with the interposition of abrasive particles which act as "third bodies" [26]. It is generally associated with the size, shape, and hardness of interstitial particles [27]. In tribology normally there are two types of abrasive wear with three bodies [28] in relation to the distance of solid bodies in motion. A first type occurs when the two bodies are distant from each other and, therefore, the abrasive particles are free to move acting as a fluid between the surfaces. The second type, instead, refers to the condition in which the two bodies are very close to each other, and therefore the abrasive particles remain trapped between the surfaces and in particular are transported by the surfaces during their relative motion causing specific types of grooves and streaks, especially when the surfaces of these bodies are wrinkled.

In the oral cavity this wear mechanism can be of a generalized or localized type [29]. When it is generalized it is usually associated with the abrasive loads of the food bolus which affects all the tooth surfaces during the chewing process.

The cumulative effect of this mechanism is to make enamel surfaces that are smooth and smooth, with rounded edges. When dentin is exposed, its softness combined with its organic substance content produces differential enamel wear.

Differential diagnosis between this wear mechanism and the corrosive one is generally difficult; if it is possible, the judgment could be made by using a microscopic examination of the surfaces expected to present a demurring layer obstructing the tubules when the wear is at the start of an abrasive type.

The study of three-bodies abrasive wear is of particular interest in the design and manufacture of toothpastes [30]. The abrasive particles present in the toothpastes, in fact, act as a third body interposed between the toothbrush and the tooth itself.

\subsubsection{Adhesive Wear}

The adhesive wear mechanism occurs when two bodies are subjected to a high contact pressure during the relative sliding. It is mainly associated with materials such as metals and polymers [31]. From a tribological point of view, the superficial asperities come into contact undergoing plastic deformation and adhering locally (micro junctions). In these cases, different amounts of material 
should be transferred from one surface to another in relation to the distance that separates the contact bodies, their mechanical and chemical properties, their surface topography [32,33], contact pressure, temperature and environment. The mass of material transferred should break during the motion increasing, but not necessarily along the original melting line. If these pieces of debris are interposed between the two sliding surfaces, three-body abrasive wear starts.

This is the wear type which, in theory, we should observe often in the oral tissues. In fact, it has been verified through in vitro tests on two-body abrasion that a transfer of matter occurs on the enamel or on a similar restorative material such as amalgam, gold and some composite materials under great pressure [5]. Nevertheless, adhesive wear is reduced for the oral tissues since the presence of saliva determines a physiological lubrification. Furthermore, the three-body abrasion caused by the food bolus tends to remove the layer of material being transferred.

\subsubsection{Fatigue Wear}

The Fatigue wear mechanism [34] occurs when a surface subjected to high pressures acts over another in a cyclic way. The deformations generated allow the surface molecules to propagate at a sub-superficial level of fragile materials, causing fractures in the intermolecular bonds. In relation to the type of material, micro-cracks should, therefore, be generated around the damaged surface and propagate as the cycles increase. When the spread approaches the surface, fragments of the material can break off and stand between the two surfaces giving rise to the aforementioned three-body abrasive wear. The delamination of superficial layers generally is the result of interactions between abrasion, adhesion and fatigue wear mechanisms $[35,36]$. Due to the high mineral content of the enamel, this has a higher hardness than dentin, but its high modulus of elasticity and low tensile strength make it fragile. The enamel is structured in prisms which prevent the propagation of micro-cracks; it is smaller at the occlusal level, where the prisms are arranged perpendicular to the surface and mineralization is maximum. When the micro-cracks formed in the surface of the tooth, in a first phase, they determine the delamination of the interprismatic substance and subsequently of the prisms themselves. These microfractures do not propagate inside the dentine thanks to the enamel-dentin junction which determines a decreasing of the mechanical stresses [37]. This wear mechanism is amplified by the cyclic repetition of axial and/or lateral loads; moreover, an acid environment should accelerate the formation of semicircular radial grooves.

\subsubsection{Corrosive Wear}

We talk about corrosive wear when the loss of tooth substance occurs due to chemical or electrochemical reactions [38]. In the dental sector it is often referred "as erosion", but we must beware of the differences in tribology when it comes to corrosive wear and erosive wear which consist of two different wear mechanisms; in fact, we refer to erosive wear [39] when the gradual reduction of substance from a surface of a solid is due to mechanical interactions between this surface and an impacting fluid or solid. Tribo-chemical wear occurs when chemical agents (acids, chelating agents) weaken the intermolecular bonds of the surface and also increase the effects of other wear processes.

This phenomenon becomes particularly critical when we refer, for example, to a wear process accompanied by acidity in the intra-buccal area linked to a gastro-regurgitation, disorders-esofagei or in the case of patients with eating disorders such as bulimia.

The main reason for corrosive wear is related to the fact that surface molecules are attacked by acids, and these molecules are then removed and the new exposed surface is again attacked by acids. In this way this mechanism of wear is the result of the cumulative effects of molecular layer removals [40].

\section{Tribological Testing}

Different dental materials were used in the experimental analyses, and different operating protocols have been developed by different authors by using tribometers to carry out wear tests. 
The experimental analyses present in the scientific literature change with respect to the materials, methods and used apparatus. Furthermore, restorative material is sometimes studied against a metal alloy (or other material) only to define its mechanical properties and its resistance to wear and corrosion. The most common configuration is the natural tooth against dental ceramics, which is the most used materials in dental restoration.

In most cases, the contact is simulated by the tribometers in pin-on-flat or ball-on-flat configurations; therefore, the geometries necessary to conduct the tests are: a flat sample (a disk or a parallelepiped) and a cylindrical pin (or a sphere). Generally, when the natural tooth is tested on dental ceramics, a dental cusp is used and a flat ceramic sample is made, but when a contact tooth is reproduced against the tooth, both pins and targets are made from natural teeth with many difficulties in the controlling of real contact surface due to the non regular natural tooth surface geometry. The tribometers used in dental tribology generally are:

\subsection{Reciprocating Tribometer}

The most common apparatus utilized to test the wear resistance of natural teeth or of prothesis materials is the reciprocating tribometer. This is characterized by a pin (cylinder) or a ball (sphere), placed in contact with a flat specimen under a vertical load causing the contact pressure, which moves along a linear stroke alternately forward and backward with an imposed frequency and stroke. In correspondence of a set of selected test parameters, this tribometer furnishes as output kinetic friction coefficient [41,42] allowing wear investigation on the worn specimens [43].

The only reproducible motion is reciprocating sliding, while impact is not taken into account. The contact conditions can be dry or lubricated; this device should be also used to test tribo-corrosion resistance.

If a lubricated condition has to be reproduced, only artificial saliva should be used because of variability of the natural saliva $\mathrm{pH}$, related to the state of health or to the food eaten by the giver. Specimens must be dipped in a saliva bath or a pump is needed to continuously supply lubricant to the contact zone. A pump is also needed for tribo-corrosive test in order to ensure a constant $\mathrm{pH}$ value (by pumping saliva and an acid liquid). In this case, the temperature has to be monitored too by a heater control unit.

Typical operating conditions are the following:

- Load: $2-20 \mathrm{~N}$

- Stroke: $1-2 \mathrm{~mm}$

- Frequency: $2 \mathrm{~Hz}$

- Numbers of cycles: $1-15,000$ Very similar to reciprocating movement test is scratch test too.

\subsection{Ball-Crater}

A bearing steel ball of selected diameter rotates against a spherical surface of a specimen. Abrasive paste and/or lubricant (artificial saliva) are then drip-fed onto the contact and a crater is abraded. The dimensions of the crater are measured using optical methods [44].

\subsection{Chewing Simulator}

A chewing simulator is the only equipment able to reproduce both impact and sliding occurring during mastication. This is a dual-axis device which can simulate the vertical and horizontal movements, by defining a stroke for the horizontal sliding and a height for the descending movement. Other parameters to define the settings of the instruments are: rising and descending speed, weight per sample, forward and backward speed, dwell time and cycle frequency [45].

By using this setup, tests are led in a chamber filled by water, saliva or other fluids (cola, fruit juice, etc.) and with a controlled temperature. 


\section{Corrosion Tests}

Corrosion (erosion) is generally considered to be the most common cause of tooth wear; moreover, enamel and dentin wear can be dramatically increase if to the sliding joins an erosive process.

Corrosion tests require the immersion of the specimen (natural tooth or prothesis material) in a substance with an acid $\mathrm{pH}$, such as cola, citric acid or fruit juice, diluted in water or artificial saliva. The latter has the capacity to remineralize enamel and it is characterized by a neutral $\mathrm{pH}$.

Hardness tests and morphological analysis are conducted before and after the immersion in the chosen liquid. Eventually, the specimen is then subject to a remineralization by immersion in saliva and, after this procedure, the hardness test and morphological analysis are executed again. This kind of test is also useful to check the ability of some toothpastes to remineralize enamel.

\section{Surface Analysis}

Nowadays, detailed surface and topographic surface analysis were execute by using optical instruments known as 3D surface profilometer/confocal.

The profilometer consists of a control unit, the main device on which is possible to position the specimens to be analyzed and of a computer to control its movements and do analyze the output data. An anti-vibration table is often present in order to cut out vibration present in the area surrounded the profilometer, limiting the influence of external factors on the measurements. The apparatus allows sophisticated optical topographical measurements of the worn contact surfaces. The roughness measurements should be performed according to the ISO 4287:1997 standard. This technique allows to gain detailed information on the status of the investigated teeth surfaces for assessing wear phenomena in a very detailed way.

Figure 1 show as example the worn surface of teeth subjected to a wear test against zirconia by using a reciprocating tribometer at the Laboratory of Applied Mechanics of the Department of Industrial Engineering (University of Salerno-IT). The images were obtained by using a confocal profilometer and show the damage of the enamel due to wear phenomena. The analysis of the surfaces in Figure 1 give information about the wear type: the surface (a) shows higher damage than the (b) in which is visible a crack, with formation of rough parallel furrows due to abrasion, according to the higher friction coefficient exhibited during the tests [46].

In Table 1 are summarized recent and relevant dental tribological investigations found in the scientific literature.

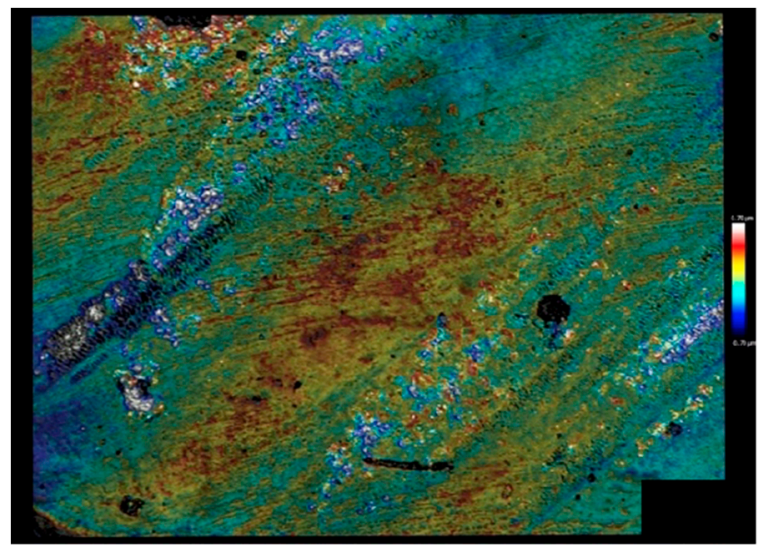

(a)

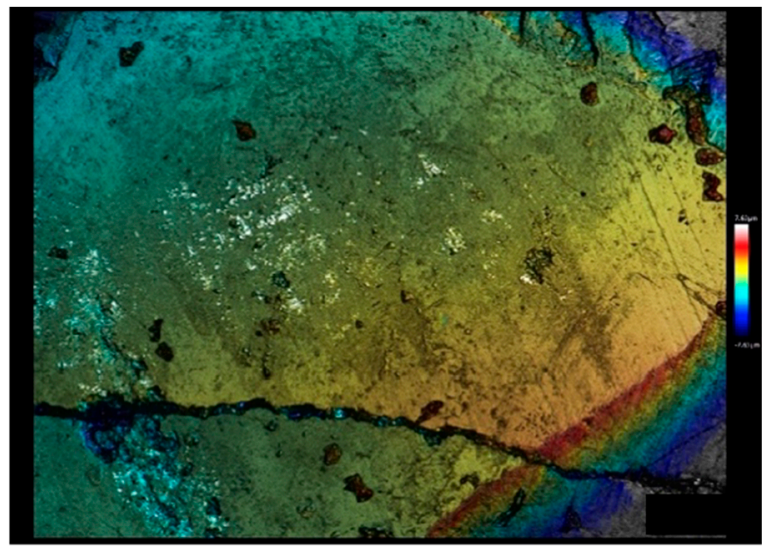

(b)

Figure 1. Example of 2D topographies of wear surfaces related to human natural tooth. 
Table 1. Recent and relevant dental tribological investigations.

\begin{tabular}{|c|c|c|c|}
\hline Publication & Materials & Methods & AIM \\
\hline $\begin{array}{l}\text { M. Eisenburger, M. Addy (2002) Erosion } \\
\text { and attrition of human enamel in vitro. } \\
\text { Part II: Influence of time and loading. } \\
\text { Part I: Interaction Effects } \\
\text { Paper: Journal of Dentistry [47] }\end{array}$ & $\begin{array}{l}\text { Two different specimens were used, } \\
\text { including a cusp and a polished flat, } \\
\text { obtained from recently extracted third } \\
\text { molars. The specimens were tested in a } \\
\text { wear simulator under neutral (saline) } \\
\text { and acidic (citric acid pH 3.2) conditions. }\end{array}$ & $\begin{array}{c}\text { Load }=200,400 \text { and } 600 \mathrm{~g} \text {; time }=10,20, \\
30 \text { min. Alternative motion between the two } \\
\text { specimens. Enamel wear was measured using } \\
\text { a profilometer. }\end{array}$ & $\begin{array}{l}\text { Determine the influence of load and time } \\
\text { on friction enamel wear, in neutral and } \\
\text { in vitro acids. }\end{array}$ \\
\hline $\begin{array}{c}\text { H. Li, Z.R. Zhou (2002) Wear behaviour of } \\
\text { human teeth in dry and artificial saliva } \\
\text { conditions. } \\
\text { Paper: Wear [48] }\end{array}$ & $\begin{array}{l}\text { Human teeth were tested under fretting } \\
\text { conditions with titanium balls (diameter } \\
\left.40 \mathrm{~mm}, \mathrm{HV}_{50 \mathrm{~g}} 240\right) \text { and } 52100 \text { steel } \\
\left(\mathrm{HV}_{50 \mathrm{~g}} 850\right) \text { both in dry and artificial } \\
\text { saliva. The specimens have been taken } \\
\text { from children undergoing orthodontics } \\
\text { treatment, cut in four parts and polished } \\
\text { to remove enamel. }\end{array}$ & $\begin{array}{l}\text { Wear test were performed under the following } \\
\text { conditions: normal load }=20 \mathrm{~N} \text {; } \\
\text { stroke = } 1 \mathrm{~mm} \text {; frequency }=2 \mathrm{~Hz} \text {; number of } \\
\text { cycles }=\text { from } 1 \text { to } 15,000 .\end{array}$ & $\begin{array}{l}\text { Analysis of the friction coefficient, wear } \\
\text { depth, wear mechanism of human teeth } \\
\text { opposing 52,100 steel and pure } \\
\text { titanium balls. }\end{array}$ \\
\hline $\begin{array}{l}\text { D. Tantbirojn, A. Huang, M.D. Ericson, } \\
\text { S. Poolthong (2008) Change in surface } \\
\text { hardness of enamel by a cola drink and a } \\
\text { CPP-ACP paste. } \\
\text { Paper: Journal of Dentistry [13] }\end{array}$ & $\begin{array}{l}\text { Twenty four extracted bovine incisors } \\
\text { were cut longitudinally in half (one half } \\
\text { to be tested and the other half as a } \\
\text { reference). The specimens were } \\
\text { embedded in orthodontic resin and } \\
\text { polished to obtain a flat enamel. }\end{array}$ & $\begin{array}{l}\text { The specimens were immersed for } 8 \mathrm{~min} \text { in } \\
6 \mathrm{~mL} \text { of coca cola before being subjected to } \\
48 \mathrm{~h} \text { of remineralization in CPP-ACP paste } \\
\text { and artificial saliva, with periodic control of } \\
\text { hardness. The remineralization was carried } \\
\text { out by subjecting the samples to a continuous } \\
\text { flow of artificial saliva }(0.4 \mathrm{~mL} / \mathrm{min}) \text {. The paste } \\
\text { was applied at } 0,8,24 \text { and } 32 \mathrm{~h} \text {. The hardness } \\
\text { was measured before and after the test (at } \\
\left.300 \mathrm{HV}_{50}\right) \text {, after } 4 \text { and } 8 \text { min of immersion and } \\
\text { after } 24 \text { and } 48 \mathrm{~h} \text { of remineralization. }\end{array}$ & $\begin{array}{l}\text { This in vitro study used surface } \\
\text { microhardness to evaluate whether a } \\
\text { paste containing casein phosphopeptide } \\
\text { amorphous calcium phosphate } \\
\text { (CPP-ACP) can reharden tooth enamel } \\
\text { softened by a cola drink, and how } \\
\text { different saliva-substitute solutions affect } \\
\text { the enamel hardness. }\end{array}$ \\
\hline $\begin{array}{l}\text { J. Zheng, R. Zhou (2007) Study of in vitro } \\
\text { wear of human tooth enamel. } \\
\text { Paper: Tribology Letters [7] }\end{array}$ & $\begin{array}{l}\text { Human teeth against titanium alloy were } \\
\text { used in the alternative ball-on-flat with } \\
\text { saliva as lubricant. The specimens were } \\
\text { extracted from human mandibular } \\
\text { second permanent molars without caries, } \\
\text { from individuals of either gender aged } \\
\text { between } 18 \text { and } 25 \text { years. The teeth were } \\
\text { cut in two parts to obtain flat polished } \\
(\mathrm{Ra}=0.2 \mu \mathrm{m}) \text { and clean specimens. The } \\
\text { measured hardness is } 360 \mathrm{HV}_{50} \text { and the } \\
\text { roughness is equal to } 0.4 \mu \mathrm{m} \text {. }\end{array}$ & $\begin{array}{l}\text { Normal load }=20 \mathrm{~N} \text {; stroke }=1 \mathrm{~mm} \text {; frequency } \\
=2 \mathrm{~Hz} \text {; numbers of cycles }=10,100,1000 \\
2000,5000 .\end{array}$ & $\begin{array}{l}\text { Study of the wear of the enamel against a } \\
\text { titanium alloy in salivary lubrication. } \\
\text { The worn surface was then observed } \\
\text { with the aid of an electron microscope. }\end{array}$ \\
\hline
\end{tabular}


Table 1. Cont.

\begin{tabular}{|c|c|c|c|}
\hline Publication & Materials & Methods & AIM \\
\hline $\begin{array}{l}\text { Camila D. Mayworm, Sergio S. Camargo } \\
\text { Jr, Fernando L. Bastian (2008) Influence of } \\
\text { artificial saliva on abrasive wear and } \\
\text { microhardness of dental composites filled } \\
\text { with nanoparticles. } \\
\text { Paper: Journal of Dentistry [10] }\end{array}$ & $\begin{array}{l}\text { Two resin-based composite restorative } \\
\text { materials were investigated. } \\
\text { Rectangular specimens of nanohybrid } \\
\text { dental composites: Esthet-Z Dentsplay } \\
\text { (64 HV) and Filtek Supreme-3M ( } 52 \mathrm{HV}) \text {. } \\
\text { Third-body wear test were conducted } \\
\text { both on the specimen just made and after } \\
62 \text { days of immersion in artificial saliva } \\
(\mathrm{pH}=6) \text {. For each test, } 6 \text { specimens of } \\
\text { each material were tested. After } \\
\text { polymerization and before performing } \\
\text { the tests, all samples were subjected to } \\
\text { sanding and polishing. }\end{array}$ & $\begin{array}{l}\text { The wear tests were carried out in a } \\
\text { ball-cratering machine. Ball cratering is a } \\
\text { technique for microabrasion test which uses a } \\
\text { rotating steel ball continuously feed with } \\
\text { abrasive slurry. Each sample was placed in } \\
\text { contact with a steel ball (radius of } 15 \mathrm{~mm}, \\
\text { rotation speed) using an aqueous aluminium } \\
\text { oxide suspension as abrading agent. A weight } \\
\text { of } 100 \mathrm{~g} \text { was applied as normal load. The tests } \\
\text { were conducted in } 50,200,500,1000, \\
1500 \text { cycles. }\end{array}$ & $\begin{array}{l}\text { The aim of this study is to compare the } \\
\text { wear resistance and hardness of two } \\
\text { dental nanohybrid composites and to } \\
\text { evaluate the influence of artificial saliva } \\
\text { storage on these properties. }\end{array}$ \\
\hline $\begin{array}{c}\text { J.A. Arsecularatne, M. Hoffman (2010) } \\
\text { On the wear mechanism of human dental } \\
\text { enamel. } \\
\text { Paper: Journal of the Mechanical Behavior of } \\
\text { Biomedical Materials [49] }\end{array}$ & $\begin{array}{l}\text { The specimens (cusp and flat) were } \\
\text { obtained from molars and premolars just } \\
\text { extracted from patients between } 22 \text { and } \\
35 \text { years. }\end{array}$ & $\begin{array}{l}\text { The cusp was put into alternative motion } \\
\text { (mean speed } 99 \mathrm{~mm} / \mathrm{min} \text { ) on a flat specimen } \\
\text { (appropriately polished and cleaned) under } \\
\text { the lubricating action of distilled water: speed } \\
99 \mathrm{~mm} / \mathrm{min} \text {; load } 2,4,8 \mathrm{~N} ; 100 \text { cycles; stroke } \\
2 \mathrm{~mm} \text {. Surface roughness analyses were } \\
\text { performed to evaluate the test result. }\end{array}$ & $\begin{array}{l}\text { Study of the processes taking place } \\
\text { below the wear surface of enamel } \\
\text { specimens from in vitro wear tests. }\end{array}$ \\
\hline $\begin{array}{l}\text { Yu-Seok Jung, Jae-Whang Lee, Yeon-Jo } \\
\text { Choi, Jin-Soo Ahn, Sang-Wan Shin, } \\
\text { Jung-Bo Huh (2010) A study on the in-vitro } \\
\text { wear of the natural tooth structure by } \\
\text { opposing zirconia or dental porcelain. } \\
\text { Paper: Journal of Advanced Prosthodontics } \\
\text { [50] }\end{array}$ & $\begin{array}{c}\text { The materials are divided into three } \\
\text { groups, for each of these } 20 \text { sample have } \\
\text { been prepared. } \\
\text { Group 1: polished feldspathic dental } \\
\text { porcelain } \\
\text { Group 2: polished zirconia } \\
\text { Group 3: zirconia with glazing }\end{array}$ & $\begin{array}{l}\text { The tests were conducted with } 240,000 \text { cycles } \\
\text { with a double axis chewing simulator. This } \\
\text { simulator has eight chambers that simulating } \\
\text { vertical and horizontal movements } \\
\text { simultaneously in the thermodynamic } \\
\text { condition. Each chamber consists of an upper } \\
\text { sample put in its holder and a lower sample } \\
\text { for use as antagonistic wear materials. } \\
\text { Premolars were used as antagonist tooth. } \\
\text { Wear was quantified by analysing the loss of } \\
\text { volume. Load }=5 \mathrm{~kg}(49 \mathrm{~N}) \text {; frequency = } \\
0.8 \mathrm{~Hz} ; \mathrm{dwell} \text { time }=60 \mathrm{~s} \text {; descending speed }= \\
30 \mathrm{~mm} / \mathrm{s} \text {; vertical movement }=6 \mathrm{~mm} ; \\
\text { horizontal movement }=0.3 \mathrm{~mm} \text {; forward } \\
\text { speed }=30 \mathrm{~mm} / \mathrm{s} \text {; backward speed }=55 \mathrm{~mm} / \mathrm{s} \text {. }\end{array}$ & $\begin{array}{l}\text { This study was conducted to evaluate } \\
\text { clinical validity of a zirconia } \\
\text { full-coverage crown by comparing } \\
\text { zirconia's wear capacity over } \\
\text { antagonistic teeth with that of } \\
\text { feldspathic dental porcelain }\end{array}$ \\
\hline
\end{tabular}


Table 1. Cont

\begin{tabular}{|c|c|c|c|}
\hline Publication & Materials & Methods & AIM \\
\hline $\begin{array}{l}\text { J.A. Arsecularatne, M. Hoffman (2011) } \\
\text { Ceramic-like wear behaviour of human } \\
\text { dental enamel. } \\
\text { Paper: Journal of the Mechanical Behavior of } \\
\text { Biomedical Materials [51] }\end{array}$ & $\begin{array}{l}\text { Specimens (cusp and flat) obtained from } \\
\text { molars and premolars extracted from } \\
\text { male patients between } 20 \text { and } 40 \text { years. }\end{array}$ & $\begin{array}{l}\text { Specimens were divided into four classes; the } \\
\text { first untested was used for comparison while } \\
\text { the other three were tested in distilled water, } \\
\text { but in three different conditions: the secondo } \\
\text { under a load of } 4 \mathrm{~N} \text {; the third under } 4 \mathrm{~N} \text { after } \\
\text { being immersed for } 20 \mathrm{~min} \text { in the cola ( } \mathrm{pH}= \\
\text { 3.4) to evaluate the reduction of hardness; the } \\
\text { fourth under a load of } 8 \mathrm{~N} \text {. The tests were } \\
\text { conducted in a scratch tester: } 200 \mathrm{cycles} \text { : } \\
\text { stroke }=2 \mathrm{~mm} \text {; alternative speed }=99 \mathrm{~mm} / \mathrm{min} \text {. } \\
\text { The friction coefficient was measured. }\end{array}$ & $\begin{array}{l}\text { This paper reported a transmission } \\
\text { electron microscopy (TEM) analysis of } \\
\text { subsurfaces of enamel specimens } \\
\text { following in vitro reciprocating wear } \\
\text { tests with an enamel cusp sliding on a } \\
\text { flat enamel specimen under hydrated } \\
\text { conditions. }\end{array}$ \\
\hline $\begin{array}{l}\text { J. Zheng, Y. Li, M.Y. Shi, Y.F. Zhang, L.M. } \\
\text { Qian, Z.R. Zhou (2013RRRr) } \\
\text { Microtribological behaviour of human tooth } \\
\text { enamel and artificial hydroxyapatite. } \\
\text { Paper: Tribology International [52] }\end{array}$ & $\begin{array}{l}\text { Nano-scratch test performed on enamel } \\
\text { specimens extracted from human } \\
\text { mandibular second permanent molars, } \\
\text { from individuals of either gender aged } \\
\text { between } 18 \text { and } 25 \text { years. Artificial } \\
\text { specimens of hydroxyapatite are } \\
\text { obtained by isostatic pressing and } \\
\text { sintering }(\mathrm{Ra}=0.1 \mu \mathrm{m}) \text {. }\end{array}$ & $\begin{array}{l}\text { Both types of specimens have been tested with } \\
\text { a conical diamond tip }(2 \mu \mathrm{m}) \text { with } \\
\text { unidirectional movement. Speed }=400 \\
\mu \mathrm{m} / \mathrm{min} \text {; scratch distance }=200 \mu \mathrm{m} \text {; normal } \\
\text { load }=5,10,20,50 \text { and } 100 \mathrm{mN} \text {. Scratch testing } \\
\text { at the progressive load mode was also } \\
\text { conducted with the loads ranging from } 5 \text { to } \\
100 \mathrm{mN} \text {. The surface was analysed with the 3D } \\
\text { profilometer, the morphologies of enamel and } \\
\text { artificial hydroxyapatite surfaces were } \\
\text { investigated by SEM and surface chemical } \\
\text { composition was measured by an } \\
\text { energy-dispersive X-ray detector (EDX). }\end{array}$ & $\begin{array}{c}\text { Study of the microtribological behavior } \\
\text { of tooth enamel and artificial } \\
\text { hydroxyapatite. }\end{array}$ \\
\hline $\begin{array}{l}\text { Lin Wang, Yihong Liu, Wenjie Si, Hailan } \\
\text { Feng, Yongqing Tao, Zhizuo Ma (2012) } \\
\text { Friction and wear behaviors of dental } \\
\text { ceramics against natural tooth enamel. } \\
\text { Paper: Journal of the European Ceramic } \\
\text { Society [53] }\end{array}$ & $\begin{array}{l}\text { Specimens obtained from four premolars } \\
\text { extracted from } 13 \text { years old males. Each } \\
\text { tooth was embedded in epoxy resin after } \\
\text { being made pulpess, with the enamel of } \\
\text { buccal surface exposed. The enamel } \\
\text { surfaces were then grounded by } \\
\text { carborundum sand paper in water, and } \\
\text { polished by } 1 \mu \text { m diamond sand paper. } \\
\text { The sample were stored in distilled water } \\
\text { during the whole process. }\end{array}$ & $\begin{array}{l}\text { The ceramic samples were made in the } \\
\text { following way: two from powder of 3Y-TZP } \\
\text { by cold isostatic pressing followed by PLS in } \\
\text { air (one sample was polished, the other was } \\
\text { left with a sintered rough surface); the lithium } \\
\text { disilicate glass ceramic sample was made by } \\
\text { hot press casting; the veneer porcelain sample } \\
\text { was shaped ad sintered. The metal specimens, } \\
\text { gold-palladium alloy and Ni-Cr alloy was } \\
\text { made by wax losing casting. The tests were } \\
\text { performed with an alternative motion in } \\
\text { artificial saliva, supervising the friction } \\
\text { coefficient. Load = } 4 \text { N; cycles = 5500. At the } \\
\text { end of the tests SEM analysis was performed. }\end{array}$ & $\begin{array}{l}\text { The aim of this article was the study of } \\
\text { the friction and wear behavior of the } \\
\text { dental ceramics against enamel of } \\
\text { natural teeth. }\end{array}$ \\
\hline
\end{tabular}


Table 1. Cont

\begin{tabular}{|c|c|c|c|}
\hline Publication & Materials & Methods & AIM \\
\hline $\begin{array}{c}\text { Matthias Scherge, Sandra Sarembre, } \\
\text { Andreas Kiesow, Matthias Petzold (2012) } \\
\text { Dental tribology at the microscale. } \\
\text { Paper: Wear [54] }\end{array}$ & $\begin{array}{l}\text { All the experiments were conducted } \\
\text { with human teeth obtained from third } \\
\text { human molars. The teeth were stored at } \\
4^{\circ} \mathrm{C} \text { in distilled water with addition of } \\
\text { ethanol and thymol. The crown of a } \\
\text { tooth was separated into } 8 \text { pieces which } \\
\text { were separately embedded into acrylic } \\
\text { resin. The topography of the sample was } \\
\text { evaluated before and after the tests with } \\
\text { a confocal laser microscope. The } \\
\text { experiments were performed in three } \\
\text { different fluids: distilled water and three } \\
\text { types of toothpaste and compared with a } \\
\text { dry contact. }\end{array}$ & $\begin{array}{l}\text { The complex macroscopic system was } \\
\text { successfully replaced by a microtribological } \\
\text { setup consisting of a single filament and a flat } \\
\text { piece of human enamel. The tooth sample was } \\
\text { placed inside a container filled with water or } \\
\text { toothpaste slurry. The container was situated } \\
\text { at the centre of a disk connected to a drive to } \\
\text { rotate the disk and specimen at a constant } \\
\text { velocity of } 0.75 \mathrm{~cm} / \mathrm{s} \text {. Loads: from } 2.4 \mathrm{mN} \text { to } \\
8 \mathrm{mN} \text { and brushing speed from } 30 \mathrm{~mm} / \mathrm{s} \text { to } \\
150 \mathrm{~mm} / \mathrm{s} \text {. }\end{array}$ & $\begin{array}{l}\text { In this work the macroscopic system of } \\
\text { brush against tooth was reduced to a } \\
\text { microtribological setup analyzing the } \\
\text { contact between a single bristle } \\
\text { (monofilament) and a tooth sample. This } \\
\text { setup allowed to correlate friction and } \\
\text { wear events to topography and structure } \\
\text { of the tooth and will enable the } \\
\text { evaluation of cleaning processes } \\
\text { microscopically in the future. }\end{array}$ \\
\hline $\begin{array}{c}\text { Jian-min Han, Hongyu Zhang, Hyo-Sun } \\
\text { Choe, Hong Lin, Gang Zheng and Guang } \\
\text { Hong (2014) Abrasive wear and surface } \\
\text { roughness of contemporary dental composite } \\
\text { resin. } \\
\text { Paper: Dental Material Journal [55] }\end{array}$ & $\begin{array}{l}\text { Evaluation of volume loss, maximum } \\
\text { wear, variation in surface roughness and } \\
\text { surface morphology (scanning electronic } \\
\text { microscopy, SEM) of } 20 \text { dental resins. } \\
\text { Five cylindrical specimens (diameter } \\
10 \mathrm{~mm} \text {, thickness } 6 \mathrm{~mm} \text { ) were made of } \\
\text { each material. The abrasive wear of the } \\
\text { materials was evaluated in the CW3-1 } \\
\text { wear machine. A rubber plate (diameter } \\
15 \mathrm{~cm} \text {, Shore hardness } 67 \text { ) was used as } \\
\text { antagonist material, immersed in a } \\
\text { mixture of } 25 \mathrm{~g} \text { of distilled water and } \\
100 \mathrm{~g} \text { of fluorite powder. }\end{array}$ & $\begin{array}{l}\text { First } 100 \text { cycles were conducted under a load } \\
\text { of } 5 \mathrm{kgf} \text { (to remove polymeric layers) and then } \\
800 \text { cycles with a load of } 17 \mathrm{kgf} \text {. }\end{array}$ & $\begin{array}{l}\text { The aim of this article was to evaluate the } \\
\text { abrasive wear and surface roughness of } \\
\text { twenty commercially available dental } \\
\text { composite resins. Loss of maximum } \\
\text { volume, maximum vertical loss of } \\
\text { roughness and surface morphology were } \\
\text { determined after wear. }\end{array}$ \\
\hline $\begin{array}{c}\text { Oscar Borrero-Lopez, Paul J. } \\
\text { Constantino, Brian R. Lawn (2018) } \\
\text { Role of particulate concentration in tooth } \\
\text { wear. } \\
\text { Paper: Journal of the Mechanical Behavior of } \\
\text { Biomedical Materials [56] }\end{array}$ & $\begin{array}{l}\text { Tooth enamel specimens were fabricated } \\
\text { from extracted human molars. Flat slices } \\
\text { parallel to occlusal surface were polished } \\
\text { to } 1 \mu \mathrm{m} \text { finish. }\end{array}$ & $\begin{array}{c}\text { Sliding wear test were conducted in a } \\
\text { ball-on-three-specimen tribometer using a } \\
\text { rotate silicon nitride sphere (radius } 6.35 \mathrm{~mm} \text { ). } \\
\text { Normal load = } 30 \mathrm{~N} \text {; sliding speed }=10 \mathrm{~mm} / \mathrm{s} \text {. } \\
\text { Before to testing, angular silica particles in a } \\
\text { water slurry were introduced between contact } \\
\text { ball and specimens in concentrations of } 0.1,0.5 \text {, } \\
1 \text { and } 5 \mathrm{vol} \% \text {. Some tests were carried out } \\
\text { without particles as a control. The tests were } \\
\text { interrupted at prescribed intervals and the } \\
\text { surface condition was measured using a } \\
\text { profilometer. }\end{array}$ & $\begin{array}{c}\text { The aim of the tests was to understand } \\
\text { how various concentrations of particle } \\
(0.1,0.5,1 \text { and } 5 \text { vol \%) can affect the rate } \\
\text { of wear. }\end{array}$ \\
\hline
\end{tabular}


Table 1. Cont.

\begin{tabular}{|c|c|c|c|}
\hline Publication & Materials & Methods & AIM \\
\hline $\begin{array}{l}\text { Ruggiero, Alessandro, et al. } \\
\text { “Experimental Comparison on Dental } \\
\text { BioTribological Pairs Zirconia/Zirconia } \\
\text { and Zirconia/Natural Tooth by Using a } \\
\text { Reciprocating Tribometer." Journal of } \\
\text { Medical Systems } 43.4 \text { (2019): 97. [57] }\end{array}$ & $\begin{array}{c}\text { Zirconia vs. zirconia and natural tooth } \\
\text { vs. zirconia }\end{array}$ & $\begin{array}{l}\text { The Research was carried out by testing the } \\
\text { above mentioned tribological pairs with the } \\
\text { use of a reciprocating tribometer under } \\
\text { lubricated conditions (artificial saliva). The } \\
\text { normal force used in the tests was } 20 \mathrm{~N} \text { the } \\
\text { time for each test was of } 60 \mathrm{~min} \text {. The stroke } \\
\text { length was } 2 \mathrm{~mm}\end{array}$ & $\begin{array}{l}\text { The aim of this research was to } \\
\text { investigate the tribological performances } \\
\text { in the tooth-to-tooth contact and } \\
\text { material-to-natural tooth contact } \\
\text { (zirconia vs. zirconia and natural tooth } \\
\text { vs. zirconia). }\end{array}$ \\
\hline
\end{tabular}




\section{Discussion and Conclusions}

The connection between tribology and dentistry is growing rapidly in the framework of biotribology. From a bibliographic search, it transpires that we passed from a few dozens of publications dealing with this topic in the 1990s to almost 500 papers in recent years, with an ever-increasing trend. Extensive research is currently being conducted to develop a better understanding of dental tribology and for a better selection of materials for dental restorations. An interesting consideration, in our opinion, is related to the fact that the keyword "tribology" or "biotribology" is little used in the medical field. A greater use of them would undoubtedly favour bibliographical research, framing this research field more clearly.

A very important consideration is certainly related to the materials used for dental restorations. These must have some basic characteristics: biocompatibility, absence of cytotoxicity, resistance to corrosion and wear resistance. Metals and alloys, composites and ceramics have been widely used for dental restorations but, compared to human tooth enamel these materials present different problems. Some of these materials are characterized by a poor biocompatibility and in some cases they were proved to be cytotoxic. Dental composites usually show inadequate wear resistance; instead the ceramic shows a better response in the oral environment.

However, there are two main problems in the dental use of ceramics: most ceramic restorations can be abrasive and potentially destructive to opposing teeth; the fragile nature of dental ceramic could cause fracture and consequently clinical issues [57]. To avoid breakage of natural teeth or dental implant, it is necessary to synthesize a material with a behavior close to human enamel. Thus, there is a need to deeply understand the microstructure of teeth, its response to masticatory forces and its wear resistance. As regards the experimental analysis, it is easy to understand that it has been very difficult to date to compare results among authors because their executive experimental investigations differ in many aspects: used apparatus (tribometerconfigurations), test conditions, material and geometry of the specimens, analyzed data (volume loss, mass loss, maximum depth of the scratch, surface roughness and/or surface morphology). For this reason, in order to easily compare the tribological behavior of different materials or of the same material under different operating conditions, and to predict the outcome in vivo, the authors believe that there is a need to standardize tribological test methods in order to define a robust wear measurement protocol to be used in dental tribology.

Funding: This research received no external funding.

Conflicts of Interest: The authors declare no conflict of interest.

\section{References}

1. Great Britain, Department of Education and Science, Lubrication Engineering (Education and Research) Working Group. Lubrication (Tribology): Education and Research; A Report on the Present Position and Industry's Needs; Jost Report; HMSO: Richmond, UK, 1966; p. 4.

2. Zhou, Z.R.; Jin, Z.M. Biotribology: Recent progresses and future perspectives. Biosurf. Biotribol. 2015, 1, 3-24. [CrossRef]

3. Koolstra, J.H. Dynamics of the Human Masticatory System. Crit. Rev. Oral Biol. Med. 2002, 13, $366-376$. [CrossRef] [PubMed]

4. Smith, B.G.; Knight, J.K. A comparison of patterns of tooth wear with aetiological factors. Br. Dent. J. 1984, 157, 16-19. [CrossRef] [PubMed]

5. Mair, L.H. Wear in dentistry-Current terminology. J. Dent. 1992, 20, 140-144. [CrossRef]

6. Scott, J.H.; Symons, N.B.B. Introduction to Dental Anatomy; Churchill Livingstone: Edinburgh, Scotland, $1982 ;$ Volume 6.

7. Zheng, J.; Zhou, Z.R. Study of in vitro wear of human tooth enamel. Tribol. Lett. 2007, 26, 181-189. [CrossRef]

8. Habelitz, S.; Marshall, S.J.; Marshall, G.W.; Balooch, M. Mechanical properties of human dental enamel on the nanometre scale. Arch. Oral Biol. 2001, 39, 173-183. [CrossRef]

9. Taher, S.M. A sample preparation technique to study the organic phase of tooth enamel under scanning electron microscopy. Mater. Res. Bull. 2000, 35, 1725-1735. [CrossRef] 
10. Mayworm, C.D.; Camargo, S.S., Jr.; Bastian, F.L. Influence of artificial saliva on abrasive wear and microhardness of dental composites filled with nanoparticles. J. Dent. 2008, 36, 703-710. [CrossRef]

11. Lussi, A.; Jaeggi, T.; Schaffner, M. Diet and dental erosion. Nutrition 2002, 18, 780-781. [PubMed]

12. Jarvinen, V.K.; Rytomaa, I.I.; Heinonen, O.P. Risk factors in dental erosion. J. Dent. Res. 1991, 70, $942-947$. [CrossRef] [PubMed]

13. Tantbirojn, D.; Huang, A.; Ericson, M.D.; Poolthong, S. Change in surface hardness of enamel by a cola drink and a CPP-ACP paste. J. Dent. 2008, 36, 74-79. [CrossRef] [PubMed]

14. Shellis, R.P.; Addy, M. The interactions between attrition, abrasion and erosion in tooth wear. Erosive Tooth Wear Monogr. Oral Sci. 2014, 25, 32-45.

15. Sperber, G.H. Dental Wear: Attrition, Erosion, and Abrasion-A Palaeo-Odontological Approach. Dent. J. 2017, 5, 19. [CrossRef] [PubMed]

16. Li, Y.; Yu, F.; Niu, L.; Hu, W.; Long, Y.; Tay, F.R.; Chen, J. Associations among bruxism, gastroesophageal reflux disease, and tooth wear. J. Clin. Med. 2018, 7, 417. [CrossRef]

17. Balasubramaniam, R.; Paesani, D.; Koyano, K.; Tsukiyama, Y. Sleep Bruxism: A Comprehensive Approach to Clinical Practice. Contemp. Oral Med. 2019, 2267-2301. [CrossRef]

18. Lund, J.P. Mastication and its control by the brainstem. Crit. Rev. Oral Biol. Med. 1991, 2, 33-64. [CrossRef]

19. Hannam, A.G.; Langenbach, G.E.J.; Peck, C.C. Computer simulation of jaw biomechanics. In Science and Practice of Occlusion; McNeill, C., Ed.; Quintessence: Chicago, IL, USA, 1997; pp. 187-194.

20. Bade, H.; Schenck, C.; Koebke, J. The function of discomuscular relationships in the human temporomandibular joint. Acta Anat. 1994, 151, 258-267. [CrossRef]

21. Schmolke, C. The relationship between the temporomandibular joint capsule, articular disc and jaw muscles. J. Anat. 1994, 184, 335-345.

22. van Loon, J.-P.; Falkenström, C.H.; de Bont, L.G.M.; Verkerke, G.J.; Stegenga, B. The theoretical optimal center of rotation for a temporomandibular joint prosthesis: A three-dimensional kinematic study. J. Dent. Res. 1999, 78, 43-48. [CrossRef]

23. Hu, X.; Zhang, Q.; Ning, J.; Wu, W.; Li, C. Study of Two-Body Wear Performance of Dental Materials. J. Natl. Med. Assoc. 2018, 110, 250-255. [CrossRef]

24. Zum Gahr, K.H. Modelling of two-body abrasive wear. Wear 1988, 124, 87-103. [CrossRef]

25. Duyck, J.; Van Oosterwyck, H.; Vander Sloten, J.; De Cooman, M.; Puers, R.; Naert, I. Magnitude and distribution of occlusal forces on oral implants supporting fixed prostheses: An in vivo study. Clin. Oral Implant. Res. 2000, 11, 465-475. [CrossRef]

26. Gates, J.D. Two-body and three-body abrasion: A critical discussion. Wear 1998, 214, 139-146. [CrossRef]

27. Trezona, R.I.; Hutchings, I.M. Three-body abrasive wear testing of soft materials. Wear 1999, 233, $209-221$. [CrossRef]

28. Godet, M. Third-bodies in tribology. Wear 1990, 136, 29-45. [CrossRef]

29. Ganss, C. Definition of erosion and links to tooth wear. Dent. Eros. 2006, 20, 9-16.

30. Ashcroft, A.T.; Joiner, A. Tooth cleaning and tooth wear: A review. Proc. Inst. Mech. Eng. Part J J. Eng. Tribol. 2010, 224, 539-549. [CrossRef]

31. Altaie, A.; Bubb, N.L.; Franklin, P.; Dowling, A.H.; Fleming, G.J.; Wood, D.J. An approach to understanding tribological 15behavior of dental composites through volumetric wear loss and wear mechanism determination; beyond material ranking. J. Dent. 2017, 59, 41-47. [CrossRef] [PubMed]

32. Merola, M.; Ruggiero, A.; De Mattia, J.S. On the tribological behavior of retrieved hip femoral heads affected by metallic debris. A comparative investigation by stylus and optical profilometer for a new roughness measurement protocol. Measurement 2016, 90, 365-371. [CrossRef]

33. Affatato, S.; Ruggiero, A.; De Mattia, J.S.; Taddei, P. Does metal transfer affect the tribological behavior of femoral heads? Roughness and phase transformation analyses on retrieved zirconia and Biolox ${ }^{\circledR}$ Delta composites. Compos. Part B Eng. 2016, 92, 290-298. [CrossRef]

34. Kruzic, J.J.; Arsecularatne, J.A.; Tanaka, C.B.; Hoffman, M.J.; Cesar, P.F. Recent advances in understanding the fatigue and wear behavior of dental composites and ceramics. J. Mech. Behav. Biomed. Mater. 2018, 88, 504-533. [CrossRef] [PubMed]

35. Ruggiero, A.; Gómez, E.; Merola, M. Experimental comparison on tribological pairs UHMWPE/TIAL6V4 alloy, UHMWPE/AISI316L austenitic stainless and UHMWPE/AL2O3 ceramic, under dry and lubricated conditions. Tribol. Int. 2016, 96, 349-360. [CrossRef] 
36. Ruggiero, A.; D'Amato, R.; Gómez, E. Experimental analysis of tribological behavior of UHMWPE against AISI420C and against TiAl6V4 alloy under dry and lubricated conditions. Tribol. Int. 2015, 92, 154-161. [CrossRef]

37. d'Incau, E.; Saulue, P. Understanding dental wear. J. Dentofac. Anom. Orthod. 2012, 15, 104-122. [CrossRef]

38. Souza, J.C.M.; Henriques, M.; Teughels, W.; Ponthiaux, P.; Celis, J.P.; Rocha, L.A. Wear and corrosion interactions on titanium in oral environment: Literature review. J. Bio- Tribo-Corros. 2015, 1, 1-13. [CrossRef]

39. Carvalho, T.S.; Colon, P.; Ganss, C.; Huysmans, M.C.; Lussi, A.; Schlueter, N.; Schmalz, G.; Shellis, R.P.; Tveit, A.B.; Wiegand, A. Consensus report of the European Federation of Conservative Dentistry: Erosive tooth wear-Diagnosis and management. Clin. Oral Investig. Sept. 2015, 19, 1557-1561. [CrossRef] [PubMed]

40. Wu, Y.Q.; Arsecularatne, J.A.; Hoffman, M. Effect of acidity upon attrition-corrosion of human dental enamel. J. Mech. Behav. Biomed. Mater. 2015, 44, 23-34. [CrossRef] [PubMed]

41. Ruggiero, A.; D'Amato, R.; Calvo, R.; Valášek, P. Measurements of the Friction Coefficient: Discussion on the Results in the Framework of the Time Series Analysis. Adv. Manuf. Eng. Mater. 2019, 443-455. [CrossRef]

42. Liguori, C.; Ruggiero, A.; Russo, D.; Sommella, P. A Statistical Approach for Improving the Accuracy of Dry Friction Coefficient Measurement. IEEE Trans. Instrum. Meas. 2019, 68, 1412-1423. [CrossRef]

43. Sripetchdanond, J.; Leevailoj, C. Wear of human enamel opposing monolithic zirconia, glass ceramic, and composite resin: An in vitro study. J. Prosthet. Dent. 2014, 112, 1141-1150. [CrossRef] [PubMed]

44. de Souza, J.A.; Dolavale, L.C.; de Souza Camargo, S.A. Wear mechanisms of dental composite restorative materials by two different in-vitro methods. Mater. Res. 2011, 16, 333-340. [CrossRef]

45. Magne, P.; Oh, W.S.; Pintado, M.R.; DeLong, R. Wear of enamel and veneering ceramics after laboratory and chairside finishing procedures. J. Prosthet. Dent. 1999, 82, 669-679. [CrossRef]

46. Ruggiero, A.; D’Amato, R.; Sbordone, L.; Haro, F.B.; Lanza, A. On the Dental BioTribology: Comparison of Zirconia/Zirconia and Zirconia/Natural Tooth Friction Coefficients by Using a Reciprocating Tribometer. In Proceedings of the Sixth International Conference on Technological Ecosystems for Enhancing Multiculturality, Salamanca, Spain, 16-24 October 2018; ACM: New York, NY, USA, 2018; pp. 440-446.

47. Eisenburger, M.; Addy, M. The wear of teeth has a multi-factorial aetiology involving the interaction of attrition, abrasion, and erosion. J. Dent. 2002, 30, 341-347. [CrossRef]

48. Li, H.; Zhou, Z.R. Wear behaviour of human teeth in dry and artificial saliva conditions. Wear 2002, 249, 980-984. [CrossRef]

49. Arsecularatne, J.A.; Hoffman, M. On the wear mechanism of human dental enamel. J. Mech. Behav. Biomed. Mater. 2010, 3, 347-356. [CrossRef] [PubMed]

50. Jung, Y.-S.; Lee, J.-W.; Choi, Y.-J.; Ahn, J.-S.; Shin, S.-W.; Huh, J.-B. A study on the in-vitro wear of the natural tooth structure by opposing zirconia or dental porcelain. J. Adv. Prosthodont. 2010, 2, 111-115. [CrossRef] [PubMed]

51. Arsecularatne, J.A.; Hoffman, M.J. Ceramic-like wear behaviour of human dental enamel. J. Mech. Behav. Biomed. Mater. 2012, 8, 47-57. [CrossRef] [PubMed]

52. Zheng, J.; Li, Y.; Shi, M.Y.; Zhang, Y.F.; Qian, L.M.; Zhou, Z.R. Microtribological behaviour of human tooth enamel and artificial hydroxyapatite. Tribol. Int. 2013, 63, 177-185. [CrossRef]

53. Wang, L.; Liu, Y.; Si, W.; Feng, H.; Tao, Y.; Ma, Z. Friction and wear behaviors of dental ceramics against natural tooth enamel. J. Eur. Ceram. Soc. 2012, 32, 2599-2606. [CrossRef]

54. Scherge, M.; Sarembre, S.; Kiesow, A.; Petzold, M. Dental tribology at the microscale. Wear 2013, 297, 1040-1044. [CrossRef]

55. Han, J.M.; Zhang, H.; Choe, H.S.; Lin, H.; Zheng, G.; Hong, G. Abrasive wear and surface roughness of contemporary dental composite resin. Dent. Mater. J. 2014, 33, 725-732. [CrossRef] [PubMed]

56. Borrero-Lopez, O.; Constantino, P.J.; Lawn, B.R. Role of particulate concentration in tooth wear. J. Mech. Behav. Biomed. Mater. 2018, 80,77-80. [CrossRef] [PubMed]

57. Ruggiero, A.; D’Amato, R.; Sbordone, L.; Blaya Haro, F.; Lanza, A. Experimental Comparison on Dental BioTribological Pairs Zirconia/Zirconia and Zirconia/Natural Tooth by Using a Reciprocating Tribometer. J. Med. Syst. 2019, 43, 1-8. [CrossRef] [PubMed]

(C) 2019 by the authors. Licensee MDPI, Basel, Switzerland. This article is an open access article distributed under the terms and conditions of the Creative Commons Attribution (CC BY) license (http://creativecommons.org/licenses/by/4.0/). 